\section{Comparison of two administration techniques of inhaled nitric oxide on nitrogen dioxide production}

Luc Dubé PhD, Martin Francoeur RRT, $\dagger$

Eric Troncy DVM MSc, $\dagger$ Raymond Carrier MSc, ${ }^{*}$

Gilbert Blaise MD $\dagger$
The purpose of this study was to verify whether, compared with the introduction of the NO- $\mathrm{N}_{2}$ mixture at the air inlet of the ventilator (classical method), a direct injection of NO$\mathrm{N}_{2}$ into the inspiratory line of the ventilator circuit with a new injection device (new method), would reduce $\mathrm{NO}_{2}$ formation by reducing contact time between $\mathrm{O}_{2}$ and NO. The effect of two $\mathrm{FrO}_{2}(0.21$ and 0.90$)$ and $\mathrm{NO}$ concentrations on $\mathrm{NO}_{2}$ production was determined. In the classical method, $\mathrm{NO}$ and $\mathrm{O}_{2}$ were mixed with an air/oxygen blender before the gas mixture entered the ventilator. In the new method, NO was injected directly into the inspiratory line with the injection system. Nitric oxide and nitrogen dioxide gases were measured using a chemiluminescence analyzer. For a $\mathrm{FlO}_{2}$ of 0.90 and 90 ppm of $\mathrm{NO}$, the amount of $\mathrm{NO}_{2}$ produced was decreased from $8.9 \pm 0.8$ ppm (mean $\pm S D$ ) with the classical injection system to 4.4 \pm 0.2 ppm with the new injection system ( $P=0.0039$, MannWhitney test), and $\mathrm{NO}_{2}$ production was decreased from $4.5 \pm$ $0.2 \mathrm{ppm}$ to $2.1 \pm 0.4 \mathrm{ppm}(P=0.02)$ at $60 \mathrm{ppm}$ of $\mathrm{NO}$. However, at a $\mathrm{FrO}_{2}$ of 0.21 , no difference was found in the amount of $\mathrm{NO}_{2}$ produced. We conclude that, compared with the classical method of NO administration, the new NO injection system reduces considerably the concentration of inhaled $\mathrm{NO}_{2}$ when a high $\mathrm{FIO}_{2}$ and a high concentration of $\mathrm{NO}$ are used.

Key words

GASES: nitric oxide, nitrogen dioxide, oxygen;

TOXICITY: nitrogen dioxide;

EQUIPMENT: blenders, injection systems, ventilators.

From the Biomedical Physics Department* and Anaesthesia Department, $\uparrow$ Notre-Dame Hospital, University of Montreal, Montreal, Quebec, Canada.

Address correspondence to: Dr. Gilbert Blaise, Department of Anaesthesia, Notre-Dame Hospital, 1560 Sherbrooke Street East, Montreal, Quebec, Canada H2L 4M1.

Accepted for publication 9th June, 1995.
Cette étude avait pour but de vérifier, si, comparativement à la méthode dintroduction du mélange $N O-N_{2}$ par l'orifice d'admission d'air du ventilateur (méthode usuelle), l'injection directe du NO- $\mathrm{N}_{2}$ dans la branche inspiratoire du circuit du ventilateur grâce à un nouveau dispositif dinjection (nouvelle méthode), réduisait la formation de $\mathrm{NO}_{2}$ en diminuant la phase de contact entre $\mathrm{O}_{2}$ et $\mathrm{NO}$. Linfluence de dewx $\mathrm{FIO}_{2}(0,21$ et 0,90) et de différentes concentrations de NO a été établie. Dans la méthode usuelle, $\mathrm{NO}$ et $\mathrm{O}_{2}$ sont réunis à l'aide d'un mélangeur d'air et d'oxygène avant leur introduction dans le ventilateur. Dans la notvelle méthode, NO est injecté directement dans la branche inspiratoire grâce au dispositif dinjection. L'oxyde nitrique et le dioxyde d'azote ont été mesurés par chimioluminescence. Pour une $\mathrm{FrO}_{2}$ de 0,90 et $90 \mathrm{ppm}$ de NO selon la méthode usuelle, la quantité de $\mathrm{NO}_{2}$ produite avec le nouveau système dinjection a diminué de $8,9 \pm 0,8 \mathrm{ppm}$ (moyenne \pm ET) à 4,4 $\pm 0,2$ ppm ( $P=0,0039$, éprewve de Mann-Whitney) alors qu'à $60 \mathrm{ppm}$ de $\mathrm{NO}$, la production de $\mathrm{NO}_{2}$ est passée de 4,5 $\pm 0,2 \mathrm{ppm}$ à 2,1 $\pm 0,4 \mathrm{ppm}(P=0,02)$. Cependant, sous une $\mathrm{FIO}_{2}$ de 0,21 , on n'a pas trouvé de différence en rapport avec la production de $\mathrm{NO}_{2}$. Les auteurs concluent que, comparativement à la méthode usuelle d'administration du NO, la nouvelle méthode par injection diminue considérablement la concentration inspirée de $\mathrm{NO}_{2}$, lorsque la $\mathrm{FrO}_{2}$ et la concentration de NO sont toutes les deux élevées.

Nitric oxide (NO) is a vasodilator released from the guanido-terminal group of L-arginine by NO synthase. ${ }^{1}$ It has a major role in cardiovascular physiology and pharmacology. ${ }^{1-4}$ In the lung, nitric oxide opposes hypoxic vasoconstriction, ${ }^{5}$ attenuates the response to vasoconstrictors $^{6}$ and maintains the pulmonary artery pressure low at rest and during exercise. ${ }^{7}$ Several nitrovasodilators such as nitroglycerin and sodium nitroprusside are donors of $\mathrm{NO},{ }^{8}$ which is the active moiety of these molecules. Nitric oxide then activates intracellular guanylate cyclase which increases the intracellular level of cGMP. This latter substance is known for being a very potent vasodilator. ${ }^{9} \mathrm{Sev}-$ eral new NO donors have been investigated, some of 
which are already in clinical use. ${ }^{10}$ Nitric oxide can also be administered as a gas in the inspiratory line to mechanically ventilated patients.

Nitric oxide has many interesting physical properties. It is a reactive free radical and reacts readily with oxygen $\left(\mathrm{O}_{2}\right)$ to form nitrogen dioxide $\left(\mathrm{NO}_{2}\right)$. Nitrogen dioxide is a potential toxic substance, and its concentration should be kept $<5 \mathrm{ppm}$ as recommended by the US Occupational Safety and Health Administration. ${ }^{11}$ The amount of $\mathrm{NO}_{2}$ in the inspiratory gas depends on the cylinder concentration of $\mathrm{NO}_{2}$ and on the production of $\mathrm{NO}_{2}$ after the introduction of NO into the ventilator or directly into the inspiratory line. The amount of $\mathrm{NO}_{2}$ produced is proportional to the concentration of $\mathrm{O}_{2}$, to the square of the concentration of $\mathrm{NO}$, and the time of contact between the two gases. ${ }^{12}$ The reaction is $2 \mathrm{NO}+\mathrm{O}_{2}=2 \mathrm{NO}_{2}$.

Very often, a mixture of $\mathrm{NO}-\mathrm{N}_{2}$ delivered by an air/ oxygen gas blender has been introduced into the air inlet of the mechanical ventilator. ${ }^{13,14}$ Some have used the cyclic flow of the nebuliser to introduce the NO- $\mathrm{N}_{2}$ mixture at the inspiratory phase. ${ }^{16}$ As an injector specifically designed to deliver NO was not available, we designed and built a new NO injection system.

Our objective was to develop an injection system that would be simple, reliable, adaptable to any ventilator or anaesthesia machine, and which could reduce $\mathrm{NO}_{2}$ production. We compared the measured concentration of $\mathrm{NO}_{2}$ in the inspiratory gas when NO was added to the air inlet of the ventilator, with the concentration of $\mathrm{NO}_{2}$ when NO was injected directly into the inspiratory line during the inspiratory phase with the new NO injection system.

Our hypothesis was that NO directly injected into the inspiratory line during the inspiratory phase by the new injector would reduce the contact time between NO and $\mathrm{O}_{2}$, and therefore, reduce $\mathrm{NO}_{2}$ production.

\section{Methods}

\section{Classical injection system}

A mixture of $\mathrm{NO}$ and $\mathrm{N}_{2}$ delivered from an air $/ \mathrm{O}_{2}$ mixer (Siemens-Elema model 961), was added to the mechanical ventilator at the air inlet. This NO- $\mathrm{N}_{2}$ mixture was then mixed with $\mathrm{O}_{2}$ by the ventilator proportional solenoid valve assembly (Figure 1). Inspiratory gases were not humidified.

\section{New injection system}

A mixture of $\mathrm{NO}-\mathrm{N}_{2}$ was directly injected into the inspiratory line of the ventilator circuit. In this new injection system, NO injection is cyclic, occurring only during the inspiratory phase of the mechanical ventilator (Figure 2). The flow was manually adjusted using a precision flowmeter made with teflon (Cole-Parmer, Niles, Illinois).

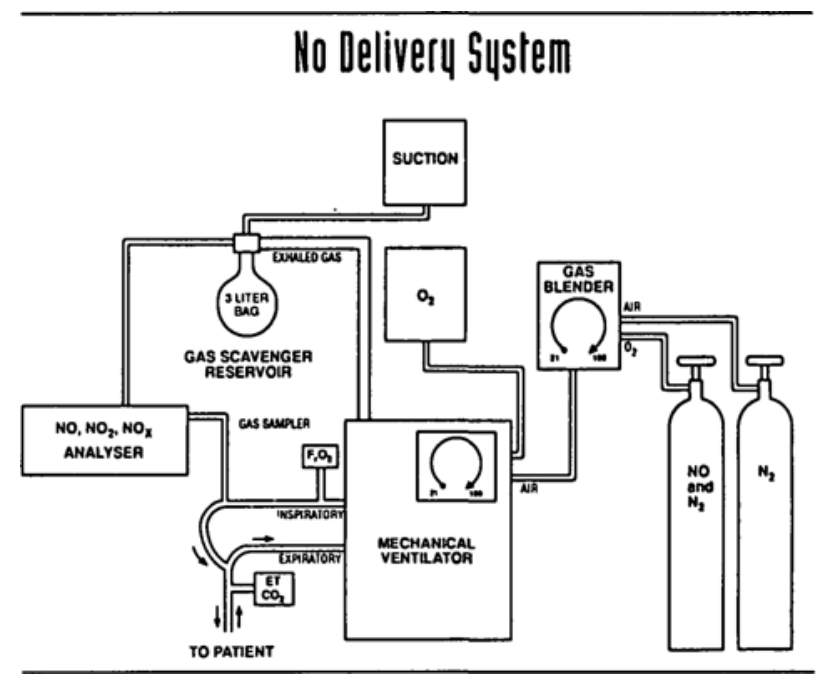

FIGURE I The classical injection system. The NO cylinder was blended with a $\mathrm{N}_{2}$ cylinder before entering the ventilator air inlet.

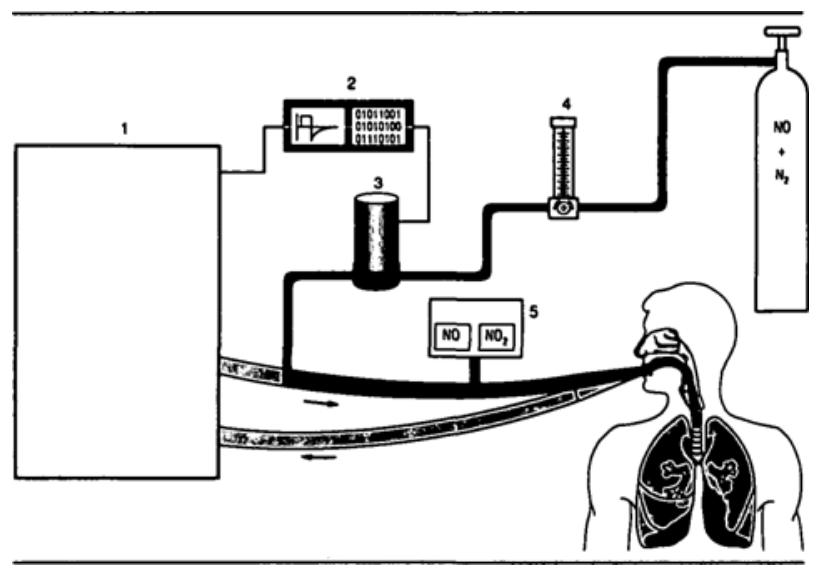

FIGURE 2 The new injection system. An electronic circuit (2) detects the beginning and the end of each inspiration by processing the signal coming from the $7200 \mathrm{AE}$ ventilator flow sensor (1). During the inspiratory phase, the electronic circuit opens the solenoid valve, which is closed when not activated (normally closed Teflon PTFE valve, Cole-Parmer, Niles, Illinois) (3) and NO is injected into the inspiratory line $60 \mathrm{~cm}$ upstream of the sampling site. At the end of the inspiratory phase, the circuit closes the solenoid valve and the injection of NO is stopped. The flow was manually adjusted using a precision flowmeter (4) made with teflon (Cole-Parmer, Niles, Illinois). The concentrations of $\mathrm{NO}$ and $\mathrm{NO}_{2}$ were continuously monitored using a chemiluminescence analyser (5).

\section{Description of protocol}

The ventilator used in this experiment was a PuritanBennett (model 7200AE, Carlsbad, California) with a disposable ventilation circuit (Puritan-Bennett \#3030) and a test lung. The new injection system could also function with any ventilator or anaesthesia machine that possesses 
an analogue flow signal output. All experiments were performed with a respiratory rate of 14 per minute, a tidal volume of $600 \mathrm{ml}$, an oxygen concentration of $21 \%$ or $90 \%$ (oxygen monitor, Hudson RCI \#5590, Temecula, $\mathrm{Ca}$ ), and an $\mathrm{I} / \mathrm{E}$ ratio of $1 / 4$. The NO cylinder was a $\mathrm{NO} / \mathrm{N}_{2}$ mixture at a concentration of $972 \mathrm{ppm}$ of NO and with minimal quantity of $\mathrm{NO}_{2}(<5 \mathrm{ppm})$ certified by the gas company (Air Liquide, Montreal).

The concentrations of $\mathrm{NO}$ and $\mathrm{NO}_{2}$ were continuously monitored using a chemiluminescence analyser (Tecan AG model CLD 700 AL, Eco Physics, Switzerland). This analyser can measure from $1 \mathrm{ppb}$ to $100 \mathrm{ppm}$, with a linearity better than $1 \%$, at a sampling rate of 660 $\mathrm{ml} \cdot \mathrm{min}^{-1}$, and was calibrated every day with a gas mixture consisting of $89 \mathrm{ppm}$ of $\mathrm{NO}$ and $5 \mathrm{ppm}$ of $\mathrm{NO}_{2}$ (Air Liquide, Montreal).

The $\mathrm{NO}$ and $\mathrm{NO}_{2}$ gases were measured in the inspiratory line $15 \mathrm{~cm}$ upstream of the $Y$ piece. In order to avoid mixture of inspiratory gases with expiratory gases, a uni-directional valve was installed in the inspiratory line just before the $\mathrm{Y}$ piece.

Measurements of $\mathrm{NO}_{2}$ were done for increasing values of NO (from 0 to $90 \mathrm{ppm}$ ). After completion of a set of measurements the NO was adjusted back to $0 \mathrm{ppm}$. At least five sets of measurements were done at the two $\mathrm{FrO}_{2}$ levels $(0.21$ and 0.90$)$.

\section{Statistics}

Due to the small sample size, at each point of NO administration, the different values of $\mathrm{NO}_{2}$ production obtained by the two systems, were compared with a MannWhitney test (significance level $\alpha=0.05$ ). Results are presented as mean $\pm \mathrm{SD}$ of $\mathrm{NO}_{2}$ production for each method of $\mathrm{NO}$ administration, at two levels of $\mathrm{FIO}_{2}$.

\section{Safety}

In order to know how well the solenoid mechanism and the electronic circuit perform over time, the injection system was tested for six weeks in the biomedical engineering laboratory. After that, the system was used in experiments using pigs (30) for $>6$ months. The injection system is CSA (Canadian Standard Association) approved. Also the injector is being used in a clinical trial, and up to now 15 patients have been treated with the system for a total of $3000 \mathrm{hr}$ without any technical problems.

The NO- $\mathrm{N}_{2}$ gas pressure, in the injection circuit, was set to one third of the maximum working pressure of the solenoid valve as recommended by the manufacturer (at $10 \mathrm{lbs} \cdot \mathrm{in}^{-2}$ ). Under these conditions, the solenoid valve lifespan should be at least 30 days of continuous operation.

The injection device has two alarms, the first is triggered by an injection time of $>7 \mathrm{sec}$ and the second

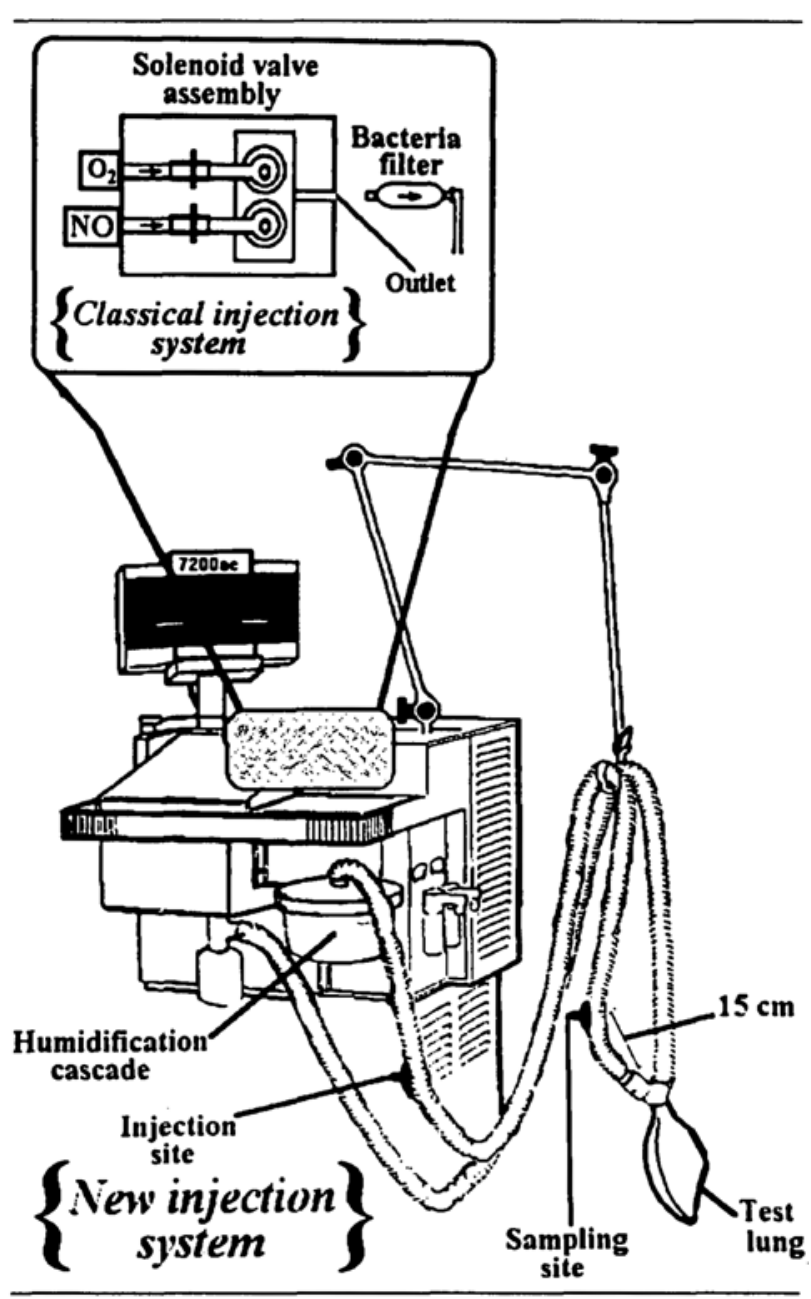

FIGURE 3 Gas mixing diagram for the classical and the new injection systems. With the classical system, $\mathrm{NO}$ and $\mathrm{O}_{2}$ interact after the solenoid valve assembly up to the sampling site in the inspiratory line of the ventilator circuit (approximately $2755 \mathrm{ml}$ ). With the new injection system, $\mathrm{NO}$ and $\mathrm{O}_{2}$ interact only from the injection site to the sampling site.

if the time between injections is $>30 \mathrm{sec}$. If the injection system fails an emergency kit is available for immediate installation and for continuous injection of NO in the inspiratory line.

\section{Contact time between $\mathrm{NO}$ and $\mathrm{O}_{2}$}

The contact time between $\mathrm{NO}$ and $\mathrm{O}_{2}$ was estimated and measured.

With the classical system, $\mathrm{NO}$ and $\mathrm{O}_{2}$ are in contact between the ventilator solenoid valve assembly, where normally $\mathrm{O}_{2}$ and air are mixed, and the sampling site in the inspiratory line of the ventilator circuit (Figure 3). From the solenoid valve assembly a $10 \mathrm{~cm}$ tube $(35$ $\mathrm{ml}$ ) leaves the ventilator, then the inspiratory gas passes through a bacterial filter (approx. $400 \mathrm{ml}$ ) and a $60 \mathrm{ml}$ 
tube between the filter and the humidification cascade $(1700 \mathrm{ml})$, and then to the inspiratory line $(560 \mathrm{ml})$ of the ventilator circuit. The total volume in which NO and $\mathrm{O}_{2}$ can interact is approximately $2755 \mathrm{ml}$. With the ventilator settings used (14 breaths per minute, tidal volume of $600 \mathrm{ml}$ and an $\mathrm{I} / \mathrm{E}$ ratio of 1/4), a time of approximately $21.5 \mathrm{sec}$, for the inspiratory gas to flow from the outlet of the ventilator to the sampling site, was anticipated for the classical injection system: it would take five breaths before NO reaches the sampling site.

To verify this the time for NO to reach the outlet of the ventilator just before the bacteria filter (after turning the blender knob from $21 \%$ to $30 \%$ ), and the time for NO to disappear completely from the outlet (after turning the blender knob back to $21 \%$ ) were measured. Also, the time for NO to reach the sampling site, and the time for NO to disappear completely from the sampling site was measured. For this purpose we used the Sievers NOA $270 \mathrm{~B}$ nitric oxide analyzer, with a response time of 200 msec for $90 \%$ of fullscale.

\section{Results}

Both nitric oxide delivery systems were able to deliver concentrations of NO from 0 to $100 \mathrm{ppm}$. The adjustment was more difficult with the classical system, because no precise blender for $\mathrm{NO} / \mathrm{N}_{2}$ exists. As expected, the increased concentration of $\mathrm{NO}$ and $\mathrm{O}_{2}$ delivered into the circuit induced an increase in the production of $\mathrm{NO}_{2}$. The total number of measurements at a $\mathrm{FiO}_{2}$ of 0.90 were $\mathbf{4 4}$ for the classical system and 36 for the new injection system. At a $\mathrm{FIO}_{2}$ of 0.21 , the total number of measurements were 37 for the classical system and 73 for the new injection system.

As seen on the curve of best fit (Figure 4) and on the bar graph (Figure 5), for a $\mathrm{FIO}_{2}$ of 0.90 and $60 \mathrm{ppm}$ of $\mathrm{NO}$, the amount of $\mathrm{NO}_{2}$ produced was decreased from $4.5 \pm 0.2$ to $2.1 \pm 0.4 \mathrm{ppm}$ with the new injection system $(P=0.02)$. The difference was also statistically significant $(P=0.0495)$ with a NO concentration of $80 \mathrm{ppm}$. At $90 \mathrm{ppm}$ of $\mathrm{NO}$, the amount of $\mathrm{NO}_{2}$ produced was decreased from $8.9 \pm 0.8$ with the classical injection system to $4.4 \pm 0.2 \mathrm{ppm}$ with the new injection system $(P=$ 0.0039 ). The lowest concentration of NO for which there was a difference in the quantity of $\mathrm{NO}_{2}$ produced was 60 ppm.

No difference in $\mathrm{NO}_{2}$ production was found between the two NO delivery systems at a $\mathrm{FIO}_{2}$ of 0.21 (Figures 6 and 7), except with a NO concentration of $50 \mathrm{ppm}$ $(P=0.02)$. This difference does not correlate with the other values obtained at a $\mathrm{FIO}_{2}$ of 0.21 , and may be due to the small sample size.

With the classical system, the fresh $\mathrm{NO}-\mathrm{N}_{2}$ gas mixture from the blender took $6.6 \pm 0.5 \sec (n=5)$ to reach

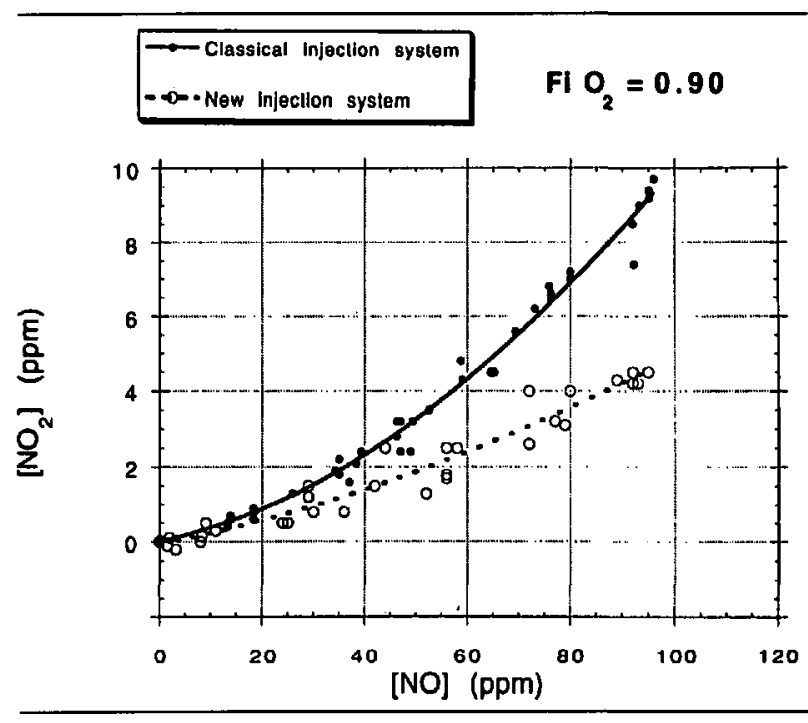

FIGURE 4 Curve of best fit of the nitrogen dioxide concentration as a function of the nitric oxide concentration for the classical $(\Theta)$ and the new injection $(\mathrm{O})$ systems, with $\mathrm{FIO}_{2}$ of 0.90 .

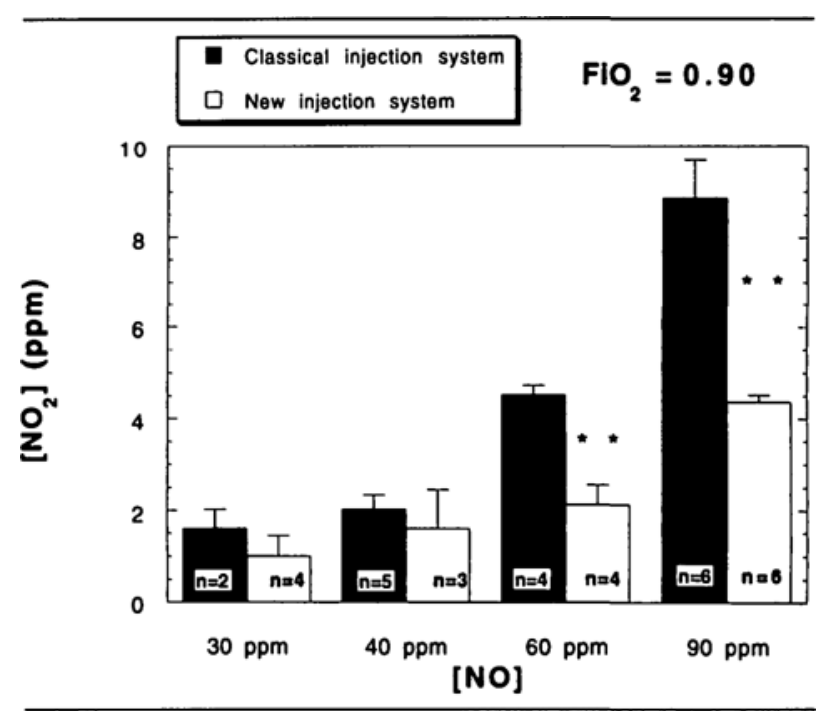

FIGURE 5 Bar graph of the nitrogen dioxide concentration as a function of the nitric oxide concentration for the classical and the new injection systems, with $\mathrm{FIO}_{2}$ of 0.90 . ${ }^{* *} P<0.05$.

the outlet of the ventilator, and $12.6 \pm 0.8 \mathrm{sec}$ to reach the sampling site. The real contact time between NO and $\mathrm{O}_{2}$ was therefore $6.0 \pm 1.3 \mathrm{sec}$. If the humidification cascade was removed, the contact time was reduced to 4.0 $\pm 1.0 \mathrm{sec}$.

We also observed that after turning off the NO supply (from $30 \%$ to $21 \%$ on the blender), it took $58.4 \pm 2.1$ $\mathrm{sec}$ to flush the ventilator circuit completely $(2755 \mathrm{ml})$ with NO-free gas, and that the contact time between NO and $\mathrm{O}_{2}$ could be as long as one minute. 


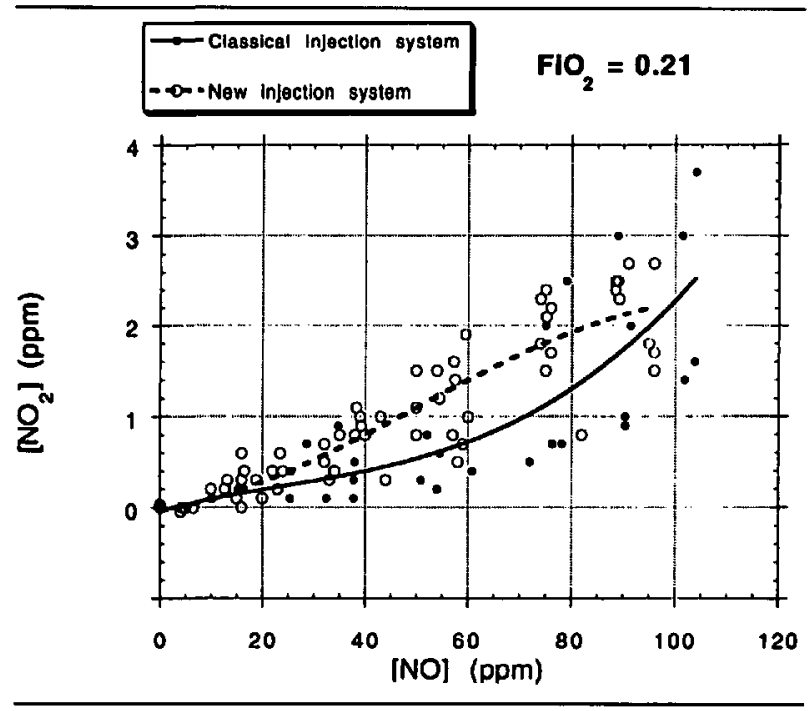

FIGURE 6 Curve of the best fit of nitrogen dioxide concentration as a function of nitric oxide concentration for the classical $(\theta)$ and the new injection $(\mathrm{O})$ systems, with $\mathrm{FIO}_{2}$ of 0.21 .

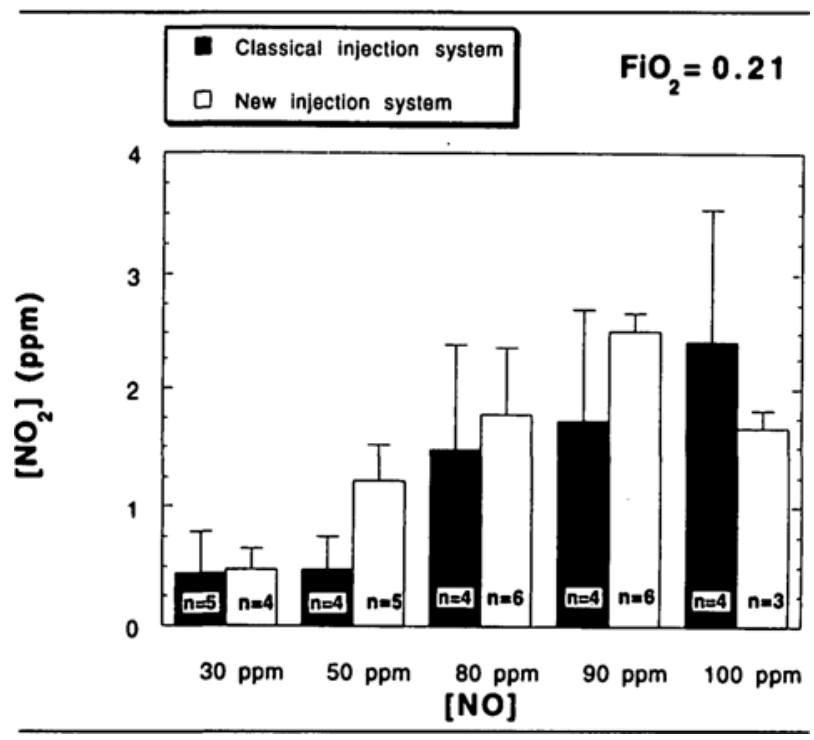

FIGURE 7 Bar graph of nitrogen dioxide concentration as a function of nitric oxide concentration for the classical and the new injection systems, with $\mathrm{FiO}_{2}$ of 0.21 .

With the new injection system, NO concentration increased during inspiration, and decreased to zero at the end of inspiration. The contact time between NO and $\mathrm{O}_{2}$ was therefore the inspiration time $(0.86 \mathrm{sec})$.

\section{Discussion}

The main finding of this study is that the new injection system reduces considerably the concentration of inhaled $\mathrm{NO}_{2}$, and can effectively deliver any concentration of $\mathrm{NO}$, when compared with the classical injection system. The contact time between $\mathrm{NO}$ and $\mathrm{O}_{2}$ can be reduced by directly injecting $\mathrm{NO}$ into the inspiratory line during the inspiratory phase, instead of adding $\mathrm{NO} / \mathrm{N}_{2}$ at the air entry of the mechanical ventilator.

During any therapy using inhaled $\mathrm{NO}, \mathrm{NO}_{2}$ concentration must be kept as low as possible. ${ }^{12}$ The amount of $\mathrm{NO}_{2}$ delivered to the patient depends on the concentration of $\mathrm{NO}_{2}$ in the NO-N $\mathrm{N}_{2}$ cylinder, the square of the concentration of NO, the concentration of $\mathrm{O}_{2}$, and the contact time between $\mathrm{O}_{2}$ and NO. Currently, nitric oxide cylinders are not medical grade and are not standardized particularly with respect to the presence of $\mathrm{NO}_{2}$ in the gas mixtures itself; hence, monitoring of the $\mathrm{NO}_{2}$ level is required to prevent toxic administration, even though the contact time between $\mathrm{NO}$ and $\mathrm{O}_{2}$ is very short.

It has been shown that $\mathrm{NO}_{2}$ in the inspiratory gas can be reduced by using soda lime or soda lime dye. ${ }^{15}$ However, Pickett et al. ${ }^{17}$ showed that soda lime with either potassium permanganate, kenazol yellow, or ethyl violet as indicator cannot be recommended for use as a nitrogen dioxide scavenger during administration of inhaled nitric oxide. Moreover, $\mathrm{NO}_{2}$ absorption is not selective because NO is also partially absorbed..$^{18}$ Consequently, the use of soda lime as a $\mathrm{NO}_{2}$ scavenger is still controversial.

In the classical injection system, the discrepancy between the anticipated $(21.5 \mathrm{sec})$ and the measured $(6.0$ sec) contact time of NO with $\mathrm{O}_{2}$, was due to the mixing (convection and diffusion) of the fresh gas with the gas present in the circuit. This mixing phenomenon could also explain why the complete elimination time of NO from the circuit is approximately one minute. It is therefore surprising that Channick et al. ${ }^{13}$ observed no $\mathrm{NO}_{2}$ production with a prolonged contact time. We also disagree with Wessel $e t$ al. ${ }^{14}$ that the classical injection system minimizes the exposure of $\mathrm{NO}$ and $\mathrm{O}_{2}$. However, our results are in agreement with Stenqvist et al..$^{15}$ and Wessel et al. ${ }^{14}$ who measured significant $\mathrm{NO}_{2}$ production.

With the new injection system, the contact time was equal to the inspiratory time which causes a reduction in $\mathrm{NO}_{2}$ production. Moreover, the direct injection of $\mathrm{NO}$ into the inspiratory line by the NO injector solves many problems encountered in the classical method of NO administration.

Mechanical ventilators use gas flow to activate certain pneumatic mechanisms (for example the $7200 \mathrm{AE}$ ventilator regulator consumption is 1 to $3.6 \mathrm{~L} \cdot \mathrm{min}^{-1}$ ). Consequently, the introduction of NO into the air inlet will increase operational costs and contribute to unnecessary pollution levels.

There is no specific $\mathrm{NO} / \mathrm{N}_{2}$ mixer available. The standard air $/ \mathrm{O}_{2}$ mixers most often in use are not accurate, despite the conclusions of Channick et al. ${ }^{13}$ and Wessel et al. ${ }^{14}$ Adjustment of precise NO concentrations is more 
difficult with these mixers, than with the new injection system.

As the $\mathrm{NO} / \mathrm{N}_{2}$ mixture is introduced into the air inlet of the ventilator, there is a risk of administering an anoxic gas to the patient. If an $\mathrm{FIO}_{2}$ of 0.21 is chosen on the ventilator, then the gases present in the inspiratory line will be exclusively $\mathrm{N}_{2}$ mixed with a few ppm of NO. The new injection system cannot give an anoxic gas mixture although the injection process will reduce the oxygen concentration. However, with both injection systems an oxygen analyser with alarms should be added in the inspiratory line in order to readjust correctly the $\mathrm{O}_{2}$ concentration.

Finally, the effect of $\mathrm{NO}$ and $\mathrm{NO}_{2}$ on different ventilator components in the classical injection system may lead to premature oxidation and could fail during a patient's treatment. We question the conclusion by Channick et al. ${ }^{13}$ and Wessel et al. ${ }^{14}$ that inhaled NO can be reliably delivered through a ventilator. No specific long-term studies were done on the oxidation process, although Wessel et al. ${ }^{14}$ indicated no problems were seen with intermittent operation, over a period of 20 months. Further studies should be performed to assess the oxidation phenomenon on ventilator components.

We conclude that the new injection system considerably reduces the concentration of inhaled $\mathrm{NO}_{2}$ compared with the classical injection method.

\section{References}

1 Moncada $S$, Higgs $A$. The L-arginine-nitric oxide pathway. N Engl J Med 1993; 329: 2002-12.

2 Furchgott RF, Zawadzki JV. The obligatory role of endothelial cells in the relaxation of arterial smooth muscle by acetylcholine. Nature 1980; $288: 373-6$.

3 Searle NR, Sahab P. Endothelial vasomotor regulation in health and disease. Can J Anaesth 1992; 39: 838-57.

4 Welch G, Loscalzo J. Nitric oxide and the cardiovascular system. J Card Surg 1994; 9: 361-71.

5 Sprague RS, Thiemermann C, Vane JR. Endogenous endothelium-derived relaxing factor opposes hypoxic pulmonary vasoconstriction and supports blood flow to hypoxic alveoli in anesthetized rabbits. Proc Natl Acad Sci USA 1992; 89: 8711-5.

6 MacLean MR, McCulloch KM, McGrath JC. Influences of the endothelium and hypoxia on $\alpha_{1}$ - and $\alpha_{2}$-adrenoceptor-mediated responses in the rabbit isolated pulmonary artery. Br J Pharmacol 1993; 108: 155-61.

7 Koizumi T, Gupta R, Newman JH. Inhibition of EDRF results in marked vasoconstriction of upstream pulmonary vessels during exercise in sheep. Am Rev Respir Dis 1993; 147: A226.

8 Harrison DG, Bates $J N$. The nitrovasodilators. New ideas about old drugs. Circulation 1993; 87: 1461-7.
9 Ignarro LJ. Biological actions and properties of endothelium-derived nitric oxide formed and released from artery and vein. Circ Res 1989; 65: 1-21.

10 Bohn H, Beyerle R, Martorana PA, Schönafinger $K$. CAS 936 , a novel sydnonimine with direct vasodilating and nitric oxide-donating properties: effects on isolated blood vessels. J Cardiovasc Pharmacol 1991; 18: 522-7.

11 NIOSH recommendations for occupational safety and health standards 1988. Center for Disease Control, Atlanta, Georgia, 1988; 37: S-7.

12 Foubert L, Fleming B, Latimer $R$, et al. Safety guidelines for use of nitric oxide (Letter). Lancet 1992; 339: 1615-6.

13 Channick RN, Newhart JW, Johnson FW, Moser KM. Inhaled nitric oxide reverses hypoxic pulmonary vasoconstriction in dogs. Chest 1994; 105: 1842-7.

14 Wessel DL, Adatia I, Thompson JE, Hickey PR. Delivery and monitoring of inhaled nitric oxide in patients with pulmonary hypertension. Crit Care Med 1994; 22: 930-8.

15 Stenqvist $O$, Kjelltoft B, Lundin S. Evaluation of a new system for ventilatory administration of nitric oxide. Acta Anaesthesiol Scand 1993; 37: 687-91.

16 Rossaint R, Falke KJ, López F, Slama K, Pison U, Zapol $W M$. Inhaled nitric oxide for the adult respiratory distress syndrome. N Engl J Med 1993; 328: 399-405.

17 Pickett JA, Moors AH, Latimer RD, Mahmood N, Ghosh $S$, Oduro $A$. The role of soda lime during administration of inhaled nitric oxide. Br J Anaesth 1994; 72: 683-5.

18 Body $S$, Russel $R$, Harlan $E$, et al. Sodalime depletes nitric oxide in a circle system. 16th Annual Meeting of the Society of Cardiovascular Anaesthesiologists, Montreal, Canada, 1994; 272. 